\title{
Sağlık Okuryazarlığının Sağlıklı Yaşam Biçimi Davranışlarıyla İlişkisi
}

\author{
The Relationship of Health Literacy with Healthy Lifestyle Behaviors
}

\author{
Hazan SOYKAN ${ }^{1}$, Halil ŞENGÜL ${ }^{2}$
}

\begin{abstract}
ÖZ
Sağlık kurumlarında çalışan personel sağlık hizmetinin daha kaliteli ve verimli olmasının sağlanmasında önemli bir rol üstlenmektedirler. Topluma sağlıklı yaşam biçimi davranışları ile örnek olması gereken sağlık profesyonellerinin, hastaların sağlıklarına yeniden kavuşabilmeleri için yardımcı olabilmeleri ve tüm hastalarla etkili bir iletişim kurabilmeleri açısından yeterli düzeyde sağlık okuryazarlığına sahip olmaları önemlidir. Bu çalışmanın amacı yüksek öğrenim öğrencilerinin sağlık okuryazarlığı ile sağlıklı yaşam biçimi davranışları arasındaki ilişkiyi incelemektir. Araştırmanın evreni, Altınbaş Üniversitesi Sağlık Meslek Yüksekokulu'nda öğrenim gören 1127 öğrenciden oluşmaktadır. Evren büyüklüğünün belli olduğu durumlarda yapılan power analizinde $\% 5$ hata, $\% 95$ güvenirlik düzeyi esas alındığında gerekli olan örneklem sayıs1 286 bulunmuştur. Araştırmaya 293 $(\% 25,38)$ öğrenci katılmıştır. Öğrencilere 16 sorudan oluşan demografik bilgiler anketi, 32 sorudan oluşan "Türkiye Sağlık Okuryazarlı̆̆ı" (TSOY-32)" ölçeği ve 52 sorudan oluşan "Sağlıklı Yaşam Biçimi Davranışları Ölçeği II” uygulanmıştır. Öğrencilerin sağlık okuryazarlığı genel ortalaması $36,20 \pm 7,66$ olarak; sağlık okuryazarlı̆ğ düzeyleri $\% 9,60$ yetersiz, $\% 28,30$ sorunlu-sınırlı, \%37,50 yeterli, \%24,60 mükemmel olarak saptanmıştır. Araştırmaya katılan öğrencilerin "Sağlıklı Yaşam Biçimi Davranışları II" ölçeğinden aldıkları ortalama puan 124,30 $\pm 23,47$ olarak tespit edilmiştir. Yapılan korelasyon analizinde sağlık okuryazarlı̆̆ı düzeyleri ile sağlıklı yaşam biçimi davranışları arasında istatiksel olarak anlamlı bir ilişki olduğu tespit edilmiştir. Öğrencilerin sağlık okuryazarlığını geliştirmek amacıyla yapılabilecek uygulamalar ve sağlığı geliştirecek davranış biçimleri için üniversitelerdeki eğitim ve teşvik planlamalarının yapılması hakkında öneriler sunulmuştur.
\end{abstract}

Anahtar Kelimeler: Sağlık Okuryazarlığı, Sağlıklı Yaşam Biçimi Davranışları, Sağlık Meslek Yüksekokulu Öğrencileri.

\begin{abstract}
Personnel working in health institutions play an important role in ensuring that the health service is of higher quality and efficiency. It is important for health professionals, who should set an example to the society with their healthy lifestyle behaviors, to have sufficient health literacy in order to help patients regain their health and to communicate effectively with all patients. The aim of this study is to examine the relationship between health literacy and healthy lifestyle behaviors of higher education students. The universe of the research consists of 1127 students studying at Altınbas University Health Vocational School. In the power analysis made in cases where the population size is certain, the required sample number was found to be 286 , based on 5\% error and $95 \%$ confidence level. $293(25.38 \%)$ students participated in the research. The demographic information questionnaire consisting of 16 questions, the "Turkey Health Literacy" (TSOY-32) scale consisting of 32 questions and the "Healthy Lifestyle Behaviors Scale II" consisting of 52 questions were applied to the students. The general average of the students' health literacy was $36.20 \pm 7.66$; health literacy levels were determined as $9.60 \%$ inadequate, $28.30 \%$ problematiclimited, $37.50 \%$ adequate, $24.60 \%$ excellent. The average score of the students participating in the study on the "Healthy Lifestyle Behaviors II" scale was determined as $124.30 \pm 23.47$. In the correlation analysis, it was determined that there was a statistically significant relationship between health literacy levels and healthy lifestyle behaviors. Suggestions were made about the practices that can be done to improve the health literacy of the students and the training and incentive plans at the universities for the behaviors that will improve the health.
\end{abstract}

Keywords: Health Literacy, Healthy Lifestyle Behaviors, Health Vocational School Students.

\footnotetext{
*Bu çalışma birinci yazarın yüksek lisans tezinden üretilmiştir. İstanbul Sabahattin Zaim Üniversitesi Etik Kurul Başkanlı̆̆’’ndan etik izin Karar No: 20292139-050.01.04) alınmıştır. 9-10 Ocak 2021 tarihinde gerçekleşen I. Sosyal Bilimler ve İnovasyon Kongresi’nde sözlü bildiri olarak sunulmuştur.

1 Öğr. Gör. Hazan SOYKAN, Tıbbi Dokümantasyon ve Sekreterlik, Altınbaş Üniversitesi Sağlık Hizmetleri Meslek Yüksekokulu, hazan.soykan@altinbas.edu.tr, ORCID: 0000-0002-9481-1917

${ }^{2}$ Doç. Dr. Halil ŞENGÜL, Sağlık Yönetimi, Sağlık Bilimleri Fakültesi, halil.sengul@izu.edu.tr, ORCID: 0000-0001-5745-0369
} 


\section{GíRiş}

Sağlık okuryazarlığı kavramı ilk olarak 1974 yilında Scott Simonds tarafindan "Health Education as Social Policy" başlikl1 makalesinde tanımlanmış olup, bugüne kadar üzerinde değişik tanımlamalar da yapılmıştır. ${ }^{1}$ Sağlık okuryazarlığı birçok çalışmaya konu olan ve araştırmacıların ilgisini çeken bir kavram olmuştur. ${ }^{2}$ Sağlık okuryazarlığ zamanlarda, sağlık hizmeti alanların tıbbi bilgiyi okuma ve anlama, sağlık ihtiyacına yönelik bu bilgileri kullanabilme yetisi olarak ifade ediliyordu. Daha sonra ortaya çıkan gelişmelerle beraber üzerinde yeniden tanımlamalar yapılmış, bireyin hem kendi sağlığını koruyucu hem de toplum sağlığını koruyucu yönde iletişim becerilerini kullanmas1, gerekli bilgilere ulaşarak bu bilgileri anlayabilmesi ve yorumlayabilmesi olarak ifade edilmiştir. ${ }^{3}$

Topluma sağlıklı yaşam biçimi davranışları ile rol model olması gereken sağlık profesyonellerinin, hastalara sağliklı olmaları için yardımcı olabilmeleri ve tüm hastalarla etkin bir şekilde iletişim kurabilmeleri açısından iyi düzeyde sağlık okuryazarlığı bilgisine sahip olmaları gerekmektedir. Sağlık çalışanlarının büyük bir bölümünü oluşturan sağlı teknisyenlerinin, hem kendileri hem de hizmet ettikleri toplum için sağlık okuryazarlığı bilgi düzeyleri değerlendirilmesi gereken bir konudur. Aynı zamanda bireyleri sağlıklı yaşam davranışları konusunda bilgilendirecek ve yönlendirecek kişiler de sağlık çalışanlarıdır. Sağlık ekibindeki her üye, sağlıkla ilgili edindiği her bilgi ve beceriyi hem yaşamına geçirmeli hem de hastalarla paylaşmalıdır. Toplum, sağlık eğitimi alan bireylerin sağlıkla ilgili attığ1 her adımı takip eder ve önemser. ${ }^{4}$ Sağlık çalışanları, mesleki sorumlulukları gereği hizmet verdiği grubu çok fazla etkilediğinden sağlığı geliştirmede büyük sorumluluklara sahiptirler.

Her gün değişen ve karmaşık bir yapıya sahip olan sağlık sisteminin amacı hastaları iyileştirmek, toplum sağlığını korumak ve koruyucu önlemler almaktır. Sağlık hizmetlerinin temel prensipleri; erken teşhis, zamanında uygulanan hizlı ve verimli tedavidir. Sağlı kurumlarında çalışan personel de sağlık hizmetinin daha kaliteli ve verimli olmasının sağlanmasında önemli bir rol üstlenmektedirler. ${ }^{5}$

Topluma sağlıklı yaşam biçimi davranışları ile örnek olması gereken sağlık profesyonellerinin, hastaların sağlıklarına yeniden kavuşabilmeleri için yardımcı olabilmeleri ve tüm hastalarla etkili bir iletişim kurabilmeleri açısından yeterli düzeyde sağlık okuryazarlığına sahip olmaları önemlidir. Sağlı çalışanlarının sağlık okuryazarlığını geliştirmek onların hastayla olan iletişimlerini kuvvetlendirir ve sağlık koşullarını iyileştirebilir. Sağlık okuryazarlığı çok geniş kapsamlı bir kavram olduğundan hasta ihtiyaçlarına cevap verebilmek için sağlık çalışanlarının sağlık okuryazarlığ 1 incelenmeli ve geliştirilmelidir. $^{6}$

Sağlık hizmetlerinde başarıyı sağlamak için en önemli etken hasta ve sağl1k çalışanları arasındaki iki yönlü iletişimin kuvvetli olması ve hasta merkezli bir anlayışa sahip olmaktır. Tıbbi koşulların karmaşıklığı sağlık personeli ile hasta arasındaki iletişimi güçleştirir. İletişimin önündeki bir diğer engel ise sağlık çalışanı ile hizmet alan arasındaki bilgi asimetrisinin olmasıdır. $^{7} \quad$ Sağlık personelinin deneyimsizliği ve uygun tıbbi dili kullanamaması hastanın onu yanlış anlamasına neden olur. Hem hastanın hem de sağlik personelinin yeterli düzeyde sağlık okuryazarlığına sahip olması ortak bir dil kullanarak anlayış eksikliğini ve kültürel farklılıkları ortadan kaldırmış olur. Hastanın ya da sağlı personelinin eğitimi, yaşı, geliri, yaşı, ırkı ne kadar iyi olursa olsun aralarında sağlık okuryazarlığı nedeniyle oluşabilecek sorunlarla karşıllaşılabilir. ${ }^{8}$

Sağlıklı yaşam biçimi davranışlarının temelleri ailede atılır, toplumda büyür ve daha sonra eğitimle değişir ve gelişir. $\mathrm{Bu}$ davranışların geliştirilmesinde sağlık çalışanlarının etkisi büyüktür. Bu yüzden ilk 
önce sağlı çalışanları kendi yaşam biçimlerini gözden geçirmeli ve düzeltmelidirler. Sağlık davranışlarının geliştirilmesi ve gelişmeye yardım eden davranışların değiştirilmesi açısından sağlık profesyonelleri örnek teşkil etmekte ve topluma model olmaları beklenmektedir. ${ }^{9}$

Bireyleri sağlıklı yaşam davranışları konusunda bilgilendirecek ve yönlendirecek kişiler sağlık çalışanlarıdır. Sağlık ekibindeki her üye, sağlikla ilgili edindiği her bilgi ve beceriyi hem yaşamına geçirmeli hem de hastalarla paylaşmalıdır. Toplum, sağlık eğitimi alan bireylerin sağlıkla ilgili attığ adımı takip eder ve önemser. ${ }^{10}$ Sağlık çalışanları, mesleki sorumlulukları gereği hizmet verdiği grubu çok fazla etkilediğinden sağlığı geliştirmede büyük sorumluluklara sahiptirler. Bu sorumluluklardan bir tanesi toplumdaki sağlıklı yaşam bilincini arttırmak, olumsuz alışkanlıkları azaltmaktır. ${ }^{11}$

Sağlık Meslek Yüksekokulu'ndaki öğrenim gören ve daha sonra sağlik profesyoneli olacak öğrencilerden, sağlıklarını geliştirmenin önemini anlamaları ve topluma örnek olmaları beklenmektedir. Mezuniyet sonrasi hem kendilerine hem çevrelerine katkı sağlayacak, sağlıklı yaşam biçimi davranışlarının geliştirilmesinde önemli rolleri bulunacaktır. Eğitim-öğretim hayatları boyunca verilen sağlık eğitimi derslerinde bu konunun üzerinde fazlaca durulmalı ve derslerde verilen teorik bilgilerin hayata geçirilmesinin sağlanarak, sonuçlarının takip edilmesi gerekmektedir. ${ }^{12}$

Koruyucu sağlik hizmetlerinin önemi son dönemde daha da belirginleşmiştir. Bireysel olarak sağlık hizmetlerinin önemsenmesi, sağlikla ilgili güncel bilgilerin topluma aksettirilmemesi gibi nedenler sağlık okuryazarlığının önemini arttırmaktadır. Toplum sağlığının gelişmesi için anahtar rolde olan bu konu hakkında birçok çalışma yapılmış ve daha fazla yapılması gerekmektedir. $\mathrm{Bu}$ araştırmanın amacı, sağlık teknikeri adaylarının sağlık okuryazarlığı ve sağlıklı yaşam biçim davranışları düzeylerini ölçmek ve aralarındaki ilişkiyi ortaya koymaktır.

\section{Araştırmanın hipotezleri;}

$\mathrm{H}^{1} \quad$ Sağlık Hizmetleri Meslek Yüksekokulu öğrencilerinin demografik özellikleri ile sağlık okuryazarlığ 1 düzeyleri arasında anlamlı bir farklılık bulunmaktadır.

$\mathrm{H}^{2} \quad$ Sağlik Hizmetleri Meslek Yüksekokulu öğrencilerinin bölümleri ile sağlık okuryazarlığı düzeyleri arasında anlamlı bir farklılık bulunmaktadır

$\mathrm{H}^{3} \quad$ Sağlık Hizmetleri Meslek Yüksekokulu öğrencilerinin demografik özellikleri ile sağlıklı yaşam biçimi davranışları arasında anlamlı bir farklılık bulunmaktadir.

$\mathrm{H}^{4} \quad$ Sağlık Hizmetleri Meslek Yüksekokulu öğrencilerinin bölümleri ile sağlıklı yaşam biçimi davranışları arasında anlamlı bir farklılık bulunmaktadır.

$\mathrm{H}^{5} \quad$ Sağlık Hizmetleri Meslek Yüksekokulu öğrencilerinin sağlık okuryazarlığ 1 düzeyleri ile sağlıklı yaşam biçimi davranışları arasında anlamlı bir ilişki bulunmaktadır.

\section{MATERYAL VE METOT}

\section{Evren ve Örneklem}

Araştırmanın evreni, Altınbaş Üniversitesi Sağlık Meslek Yüksekokulu'nda öğrenim gören 1127 öğrenciden oluşmaktadır. Evren büyüklüğünün belli olduğu durumlarda yapılan power analizinde $\% 5$ hata, $\% 95$ güvenirlik düzeyi esas alındığında gerekli olan örneklem sayısı 286 bulunmuştur. Toplamda araştırmaya 293 öğrenci katılmıștır.

\section{Verilerin Toplanması}

Verilerin toplanmasinda Okyay ve arkadaşları (2016) tarafından geliştirilen 'Türkiye Sağlı Okuryazarlığı Ölçeği (TSOY-32)" ile Bahar ve arkadaşları (2008) tarafından geçerlik güvenilirlik analizleri yapılan "Sağlıklı Yaşam Biçimi Davranışları Ölçeği II” kendilerinden gerekli izin alınarak kullanılmıştır. ${ }^{12,13} \quad$ Sağlık Meslek Yüksekokulu öğrencilerine uygulanan bu 
ölçeğin ilk kısmında öğrencilerin kişisel bilgileri, ikinci kısımda ise sağlık okuryazarlığı ve sağlıklı yaşam biçimi davranışlarının ölçüldüğü sorular yer almaktadır.

\section{Kişisel Bilgi Formu}

Öğrencilerin demografik bilgileri tespit etmek için oluşturulan soru formudur. Kişisel değişkenleri ile ilgili olarak cinsiyet, yaş, bölüm, doğum yeri, aile gelir durumu vb. değişkenlerini içeren sorular yer almaktadır.

\section{Türkiye Sağlık Okuryazarlığı (TSOY-32)}

HLS-EU (European Health Literacy Survey) temel alınarak geliştirilen bu ölçek Okyay ve ark. tarafindan 2016 yılinda geçerlik güvenirliği yapılmış ve Türkiye'de 15 yaş ve üzeri kişilere uygulanmaya başlanmıştır. TSOY-32 orijinal ölçekten farklı olarak üç değil iki temel boyut alınarak uygulanmıștır. Bu uygulamaya göre $2 \mathrm{X} 4$ lük matris Tedavi ve hizmet, Hastaliklardan korunma/Sağlı̆̆ın geliştirilmesi boyutları ve dört süreç olan sağlıkla ilgili bilgiye ulaşma, sağlıkla ilgili bilgiyi anlama, sağlıkla ilgili bilgiyi değerlendirme, sağlıkla ilgili bilgiyi kullanma/uygulama olarak sekiz bileșenden oluşmaktadır. Toplam soru sayısı 32'dir. Ölçeğin puanlamasında ortalama puanlar, "çok zor" seçeneğine 1 puan, "zor" seçeneğine 2 puan, "kolay" seçeneğine 3 puan, "çok kolay" seçeneğine 4 puan, "Fikrim yok" seçeneği 0 puan verilmek suretiyle hesaplanmıştır. Sorular $1 \rightarrow 4,2 \rightarrow 3$, $3 \rightarrow 2, \quad 4 \rightarrow 1, \quad 5 \rightarrow 0$ olacak şekilde tekrar kodlanarak toplam puan ve ortalama puan hesaplanmıştır. Ölçeğin değerlendirilmesinde HLS-EU ölçeğinde olduğu gibi puanlar 0-50 arasında olacak şekilde kategorize edilmiştir. Bunun için aşağıdaki formül kullanılmıştır:

$$
\text { İndeks }=(\text { ortalama-1) } \times(50 / 3)
$$

$\mathrm{Bu}$ formüldeki indeks öğrencilerin cevapladığ 1 her bir sorunun ortalamasını ifade etmektedir. $\mathrm{Bu}$ puanlamadan çıkan sonuçlar 4 kategoriye ayrılmış ve sağlık okuryazarlığı düzeyleri belirlenmiştir.

(0-25) : yetersiz sağlık okuryazarlığı

(>25-33) : sorunlu - sınırlı sağlik okuryazarlığ 1
(>33-42) : yeterli sağlık okuryazarlığ

(>42-50) : mükemmel sağlık okuryazarlığı, olarak tanımlanmaktadır. ${ }^{15}$

Orijinal ölçeğin kapsam geçerliği uzmanların değerlendirme puanlarına başvurularak sağlanmış ve iç tutarlık güvenirliği için Cronbach alpha katsayısı incelenmiştir. Ölçeğin Cronbach alpha güvenirlik katsayıs1 0,920 bulunmuştur. Ölçeğin alt boyutlarından 'Tedavi ve Hizmet' için güvenilirlik katsayısı 0,853 'Hastalıklardan Korunma/Sağlı̆̆ın Geliştirilmesi' için güvenilirlik kaysayısı 0,873 olarak hesaplanmıştır.

\section{Sağlıklı Yaşam Biçimi Davranışları Ölçeği II (SYBD-II)}

Walker ve ark. (1996) tarafindan geliştirilen bu ölçek Bahar ve ark. (2008) tarafından geçerlik güvenirlik analizleri yapılarak Türkçeye uyarlanmıştır. Bu ölçekte toplam 52 madde bulunmaktadır. Ölçek, hiçbir zaman (1), bazen (2), sik sik (3), düzenli olarak (4) olarak derecelendirilerek puanlanmıştır. Sağlık Sorumluluğu $(3,9,15,21,27,33,39,45,51)$, Fiziksel Aktivite $(4,10,16,22,28,34,40,46), \quad$ Beslenme $(2,8,14,20,26,32,38,44,50)$, Manevi Gelişim $(6,12,18,24,30,36,42,48,52), \quad$ Kişilerarası İlişkiler $(1,7,13,19,25,31,37,43,49)$ ve Stres Yönetimi $(5,11,17,23,29,35,41,47)$ olmak üzere altı alt boyutu vardır. ${ }^{14}$ Ölçeğin alt boyutlarının güvenirlik katsayıları sırayla; 0,$794 ; 0,793 ; 0-692 ; 0,844 ; 0,819$; $0,718^{`}$ dir.

\section{Araştırmanın Etik Yönü}

Verilerin toplanması süreci, İstanbul Sabahattin Zaim Üniversitesi Etik Kurul Başkanlığının 31.12.2019 tarihli 20292139050.01.04 sayılı etik kurul onayı ve Altınbaş Üniversitesi Sağlık Hizmetleri Meslek Yüksekokulu Müdürlüğü'nden alınan idari izinlerden sonra 15.01.2020-28.02.2020 tarihleri arasında Altınbaş Üniversitesi SHMYO öğrencilerinin dersleri ve sinavları için ayrılan süre ihlal edilmeden sorumlu öğretim üyeleri yardımı eşliğinde gerçekleştirildi. Öğrencilere araştırmanın konusu ve amacı hakkında bilgiler verilmiş, gönüllü olarak katılımları sağlanmıştır. 
Araştırma, Altınbaş Üniversitesi Sağlık Hizmetleri Meslek Yüksekokulu öğrencilerine yapılmış, toplamda 293 öğrenciye ulaşılmıştır. Her bir anket ortalama 10-20 dakika içerisinde doldurulmuştur.

\section{Verilerin Değerlendirilmesi}

Araştırma sonucunda elde edilen veriler SPSS $22.0 \quad$ programı aracılığıyla değerlendirilmiştir. Değişkenlerin normal dağılıma uygunluğu Shapiro Wilks testi ile değerlendirilmiş ve verilerin normal dağılıma uygunluk gösterdiği saptanmıştır. TSOY-32 ölçeğinin kapsam geçerliği uzmanların değerlendirme puanlarına başvurularak sağlanmış ve iç tutarlık güvenirliği için Cronbach alpha katsayısı incelenmiştir. Ölçeğin Cronbach alpha güvenirlik katsayısı 0,920 bulunmuştur. Ölçeğin alt boyutlarından 'Tedavi ve Hizmet' için güvenilirlik katsayısı 0,853 'Hastalıklardan Korunma/Sağlığın Geliştirilmesi' için güvenilirlik kaysayısı 0,873 olarak hesaplanmıştır. SYBD-II ölçeğinin alt boyutlarının güvenirlik katsayıları sirayla; 0,794;0,793;0,692 ; 0,$844 ; 0,819 ; 0,718^{\prime}$ dir. Tanımlayıcı istatistiksel metotlar için ortalama, standart sapma, frekans, yüzde değerleri ve katılımcıların demografik özelliklere göre farklılığını ortaya koymak için bağımsız $\mathrm{t}$ testi ve ANOVA (tek yönlü varyans analiz) testi yapılmıştır. Ölçek puanları arasındaki ilişkinin değerlendirilmesinde Pearson Korelasyon Analizi ve sağlik okuryazarlığının sağlıklı yaşam biçimi davranışları üzerindeki etkisini görmek için de Regresyon Analizi kullanılmıştır.

\section{Kisıtlılıklar ve Varsayımlar}

Araştırma, bir vakıf üniversitesinde okuyan Sağlık Meslek Yüksekokulu öğrencilerine yapılması nedeniyle sonuçları bütün Sağlık Hizmetleri Meslek Yüksekokulu öğrencileri için genellenemez. Çalışmaya katılan öğrencilerin gerçek düşüncelerini yansıttığı varsayılmıştır.

\section{BULGULAR VE TARTIŞMA}

\section{Öğrencilerin Demografik Özellikleri}

Örneklem grubunu oluşturan 293 öğrencinin 226'sı kadın, 67'si erkektir. 163'ü 18-20 yaş aralığında, 119'u 21-23 yaş aralığında, 7'si 24-26 yaş aralığında, 4'ü 26 yaş üzeridir. 188 'i büyükşehirde, 62'si kent merkezinde, 43'ü ise köyde doğmuştur (Tablo 1).

Öğrencilerin 89'u 1. sinıf, 204'ü 2. sinıf ve 42'si Ağız ve Diş Sağlı̆̆1, 25'i Ameliyathane Hizmetleri, 52'si Anestezi, 24'ü İlk ve Acil Yardım, 37'si Odyoloji, 53'ü Radyoterapi, 31'i Tibbi Dokümantasyon ve Sekreterlik, 29'u Tibbi Görüntüleme Teknikleri Bölümü öğrencisidir (Tablo 1).

Öğrencilerin; 11'inin maddi durumunun kötü, 190'ının orta düzeyde olduğu; 211 öğrencinin annesinin, 183 öğrencinin de babasının ilköğretim bölümü mezunu olduğu görülmektedir (Tablo 1).

Öğrencilerin VKI'lerine göre 38'i zayıf, 199'u normal kilolu, 55'i kilolu grupta yer almaktadır. öğrencilerin vücut kitle indeksleri, vücut ağırlığının boyun metre cinsinde karesine oranlanması ile (ağırlık / boy2, $\mathrm{kg} / \mathrm{m} 2$ ) formülünden elde edilmiş, $\mathrm{VKI}<18.50$ zay1f, VKI: $18.50-24.9$ aras1 normal kilolu, VKI: 25-29.9 aras1 kilolu, VKI $>30$ şişman olarak değerlendirilmiştir. ${ }^{14}$ Araştırmada 20 öğrencinin kronik bir rahatsızlığının olduğu, 76 öğrencinin daha önce ameliyat geçirdiği, 94 öğrencinin aktif sigara kullanıcı olduğu ve 31 öğrencinin daha önce Sağlık Okuryazarlığ 1 eğitimine katıldığ bilgileri de edinilmiştir (Tablo 1). 
Tablo 1. Öğrencilere Ait Demografik Dağılım

\begin{tabular}{|c|c|c|c|}
\hline & & $\mathbf{n}$ & $\%$ \\
\hline \multirow{5}{*}{ Yaş (yıl) } & $18-20$ & 163 & 55,6 \\
\hline & $21-23$ & 119 & 40,7 \\
\hline & $24-26$ & 7 & 2,4 \\
\hline & 26 ve üzeri & 4 & 1,3 \\
\hline & Min-Maks, Ort \pm SS & $18-31$ & $20,00 \pm 0,93$ \\
\hline \multirow{2}{*}{ Cinsiyet } & Kadın & 226 & 77,1 \\
\hline & Erkek & 67 & 22,9 \\
\hline \multirow{3}{*}{ Doğum yeri } & Köy/Kasaba & 43 & 14,7 \\
\hline & Kent Merkezi & 62 & 21,2 \\
\hline & Büyükşehir & 188 & 64,2 \\
\hline \multirow{2}{*}{ Medeni Durum } & Evli & 2 & 0,7 \\
\hline & Bekar & 291 & 99,3 \\
\hline \multirow{2}{*}{ Sinıf } & 1 & 89 & 30,4 \\
\hline & 2 & 204 & 69,6 \\
\hline \multirow{8}{*}{ Bölüm } & $\begin{array}{l}\text { Ağız ve Diş } \\
\text { Sağlığı }\end{array}$ & 42 & 14,3 \\
\hline & $\begin{array}{l}\text { Ameliyathane } \\
\text { Hizmetleri }\end{array}$ & 25 & 8,5 \\
\hline & Anestezi & 52 & 17,7 \\
\hline & $\begin{array}{l}\text { İlk ve Acil } \\
\text { Yardım }\end{array}$ & 24 & 8,2 \\
\hline & Odyoloji & 37 & 12,6 \\
\hline & Radyoterapi & 53 & 18,1 \\
\hline & $\begin{array}{l}\text { T1bbi } \\
\text { Dokümantasyon } \\
\text { ve Sekreterlik }\end{array}$ & 31 & 10,6 \\
\hline & $\begin{array}{l}\text { Tibbi Görüntüleme } \\
\text { Teknikleri }\end{array}$ & 29 & 9,9 \\
\hline \multirow{3}{*}{ Maddi Durum } & Kötü & 11 & 3,8 \\
\hline & Orta & 190 & 64,8 \\
\hline & İyi & 92 & 31,4 \\
\hline \multirow{3}{*}{$\begin{array}{l}\text { Anne Eğitim } \\
\text { Durumu }\end{array}$} & İlköğretim & 211 & 72 \\
\hline & Lise & 67 & 22,9 \\
\hline & Lisans ve üzeri & 15 & 5,1 \\
\hline \multirow{3}{*}{$\begin{array}{l}\text { Baba Eğitim } \\
\text { Durumu }\end{array}$} & İlköğretim & 183 & 62,5 \\
\hline & Lise & 80 & 27,3 \\
\hline & Lisans ve üzeri & 30 & 10,2 \\
\hline \multirow{4}{*}{$\begin{array}{l}\text { Vücut Kitle } \\
\text { İndeksi }\end{array}$} & Zayıf & 38 & 13 \\
\hline & Normal & 199 & 67,9 \\
\hline & Kilolu & 55 & 18,8 \\
\hline & Şişman & 1 & 0,3 \\
\hline \multirow{2}{*}{$\begin{array}{l}\text { Kronik bir } \\
\text { rahatsızlık }\end{array}$} & Var & 20 & 6,3 \\
\hline & Yok & 273 & 86,4 \\
\hline \multirow{2}{*}{$\begin{array}{l}\text { Daha önce } \\
\text { ameliyat } \\
\text { geçirme }\end{array}$} & Evet & 76 & 25,9 \\
\hline & Hayır & 217 & 74,1 \\
\hline \multirow{2}{*}{$\begin{array}{l}\text { Sigara } \\
\text { kullanma }\end{array}$} & Kullanıyor & 94 & 32,1 \\
\hline & Kullanmiyor & 199 & 67,9 \\
\hline $\begin{array}{l}\text { Daha önce } \\
\text { "Sağlık }\end{array}$ & Evet & 31 & 10,6 \\
\hline $\begin{array}{l}\text { Okuryazarlığı" } \\
\text { eğitimine } \\
\text { katılma }\end{array}$ & Hayır & 262 & 89,4 \\
\hline
\end{tabular}

\section{Öğrencilerin Sağlık Okuryazarlı̆ğı} Özellikleri ve İlişskili Faktörler

Öğrencilerin TSOY-32 Sağlı Okuryazarlığ ölçeğine verdikleri cevapların madde dağılımlarına göre cevap yüzdelerinde katılımcıların çoğunun en çok verdikleri cevaplar 32 sorunun 14'üne "çok kolay"; 16 'sina "kolay" olduğu görülmektedir.

6. Maddeye ait olan "Bir sağlık kuruluşuna gitmek istediğinizde, telefon ya da internet aracıllğı ile randevu almak" ifadesi en yüksek orandaki (\%58) "çok kolay";

2. maddeye ait olan "Sağlığınızla ilgili bir şikayetiniz olduğunda, bu konudaki herhangi bir yazıyı (broşür, kitapçık, afiş gibi) okuyup anlamak" ifadesi en yüksek orandaki $(\% 52,90)$ "kolay";

15. maddeye ait olan" Acil bir durumda (kaza, ani sağllk sorunu gibi) ne yapabileceğine karar vermek" ifadesi en yüksek orandaki $(\% 31,40)$ "zor";

32. maddeye ait olan "Sağlikla ilgili politika değişikliklerini yorumlamak" ifadesi en yüksek orandaki $(\% 9,20-\% 6,10)$ "çok zor" ve "fikrim yok" cevaplarıdır.

Öğrencilerin TSOY-32 Sağlı Okuryazarlığı ölçeğinin alt boyutları indeks puan ortalamaları Tablo 2 : Öğrencilerin Sağlık Okuryazarlığı Ölçeği Alt Boyutları İndeks Puan Ortalamaları'nda verilmiştir. Bu cevaplara göre öğrencilerin en yüksek puan ortalamas1 "Tedavi ve Hizmet" boyutunun "Sağlıkla ilgili bilgiye ulaşma" sürecinde $(38,45 \pm 9,70)$; en düşük puan ortalamas1 "Hastalıklardan korunma/Sağlığın geliștirilmesi" boyutunun "Sağlıkla ilgili bilgiyi kullanma/uygulama" sürecinde $(32,77 \pm 10,53)$ olduğu görülmektedir. 
Tablo 2. Öğrencilerin Sağlık Okuryazarlığı Ölçeği Alt Boyutları İndeks Puan Ortalamaları

\begin{tabular}{lrc}
\hline & Min-Max & Ort. \pm SS \\
\hline Genel & $2,67-50$ & $36,20 \pm 7,66$ \\
\hline Tedavi ve Hizmet & $5,50-50$ & $36,88 \pm 7,95$ \\
\hline $\begin{array}{l}\text { Bilgiye ulaşma } \\
\text { Bilgiyi anlama } \\
\text { Bilgiyi değerlendirme }\end{array}$ & $0-50$ & $38,45 \pm 9,70$ \\
$\begin{array}{l}\text { Bilgiyi } \\
\text { kullanma/uygulama }\end{array}$ & $0-50$ & $38,48 \pm 8,88$ \\
$\begin{array}{l}\text { Hastalıklardan } \\
\text { korunma ve sağlığın } \\
\text { geliştirilmesi }\end{array}$ & $0-50$ & $33,02 \pm 9,97$ \\
\hline $\begin{array}{l}\text { Bilgiye ulaşma } \\
\text { Bilgiyi anlama }\end{array}$ & $0-50$ & $37,75 \pm 10,08$ \\
\hline $\begin{array}{l}\text { Sağlıkla ilgili bilgiyi } \\
\text { anlama }\end{array}$ & $0-50$ & $37,62 \pm 9,24$ \\
\hline $\begin{array}{l}\text { Sağlıkla ilgili bilgiyi } \\
\text { değerlendirme }\end{array}$ & $0,50,13,17$ \\
\hline $\begin{array}{l}\text { kullanma ilgili bilgiyi } \\
\text { kullanma/uygulama }\end{array}$ & $0-50$ & $32,77 \pm 10,53$ \\
\hline $\begin{array}{l}\text { Sağlıkla ilgili bilgiye } \\
\text { ulaşma }\end{array}$ & $0-50$ & $38,14 \pm 8,87$ \\
\hline & $0-50$ & $33,22 \pm 11,30$ \\
\hline
\end{tabular}

Sağlık okuryazarlığı indeks puanlarına göre öğrencilerin sağlık okuryazarlığ düzeyleri ve yüzdeleri Tablo 3 : Öğrencilerin Genel Sağlık Okuryazarlığı Düzeylerinin Yüzde Oranları'nda gösterilmiştir. Öğrencilerin en çok “yeterli” düzeyde $(\% 37,50)$, en az yetersiz düzeyde $(\% 9,60)$ sağlık okuryazarlığına sahip olduğu görülmektedir.
Tablo 3. Öğrencilerin Genel Sağlık Okuryazarlığı Düzeylerinin Yüzde Oranları

\begin{tabular}{lrc}
\hline Sağlık Okuryazarlığı Düzeyleri & n & \% \\
\hline Yetersiz (0-25)puan & 28 & 9,6 \\
Sorunlu-Sınırlı (>25-33) puan & 83 & 28,3 \\
Yeterli (>33-42) puan & 110 & 37,5 \\
Mükemmel (>42-50) puan & 72 & 24,6 \\
\hline
\end{tabular}

Öğrencilerin demografik özellikleri ile sağlık okuryazarlığı ilişkileri incelendiğinde sadece kronik hastalığa sahip olan öğrencilerin $39,57 \pm 5,07$; kronik hastalığ olmayan ögrrencilerin $35,96 \pm 7,77$ ortalamaya sahip olması dikkat çekmektedir. Kronik hastalığı olan öğrencilerin sağlık okuryazarlığ 1 ortalaması daha yüksektir. Öğrencilerin kronik hastalık durumlarına göre indeks puanları incelenmiş istatistiksel açıdan anlamlı bir farklılık tespit edilmiştir $(t=2,042 ; p=0,042)(p<0,05)$.

\section{Öğrencilerin Sağlıklı Yaşam Biçimi} Davranışları Özellikleri ve İlişkili Faktörler

Araştırmaya katılan öğrencilerin çoğunluğunun 52 sorudan 43'üne "Belki", 7'sine "Sık S1k" , 2'sine "Hiçbir Zaman"; 1 'ine "Düzenli Olarak" cevabını vermişlerdir.

40. soru olan "Egzersiz yaparken nabız ve kalp atışlarımı kontrol ederim" $(\% 36,18)$ ve 45. soru olan "Bireysel sağlık bakımı ile ilgili eğitim programlarına katılırım" $(\% 42,66)$ sorularında "Hiçbir Zaman", 48. Soru olan "İlahi bir gücün varlığına inanırım" $(\% 42,32)$ sorusunda "Düzenli Olarak" seçeneklerinin yüzdelerinin en yüksek değerlerde olması dikkat çekmektedir.

"Düzenli Olarak" seçeneği en yüksek 42. soru olan "Yaşamımda benim için önemli olan şeylerin farkındayım" maddesinde $(\% 41,30)$, "Belki" seçeneği en yüksek 44. Soru olan "Gida paketlerinin üzerindeki besin, yağ ve sodyum içeriklerini belirleyen 
etiketleri okurum" maddesinde $(\% 50,51)$ görülmektedir.

Öğrencilerin "Sağlıklı Yaşam Biçimi Davranışları Ölçeği II" puanları Tablo 4 : Öğrencilerin SYBD II Ölçeği Puanlarının Ölçek Boyutlarına Göre İncelenmesi'nde verilmiştir. En yüksek ortalamanın "Manevi Gelişim" boyutunda $(24,25 \pm 5,32)$, en düşük ortalamanın ise "Fiziksel Aktivite" boyutunda $\quad(16,67 \pm 4,71) \quad$ olduğu görülmektedir. Öğrencilerin SYBD II ölçeğinden aldıkları toplam puanların ortalaması 124,30 $\pm 23,47$ olarak bulunmuştur.

Tablo 4. Öğrencilerin SYBD II Ölçeği Puanlarının Ölçek Boyutlarına Göre İncelenmesi

\begin{tabular}{lrrr}
\hline $\begin{array}{l}\text { SYBD Ölçeği } \\
\text { Altboyutları }\end{array}$ & $\begin{array}{r}\text { Soru } \\
\text { Sayısı }\end{array}$ & Min-Max & Ort. \pm SS \\
\hline $\begin{array}{l}\text { Sağlık } \\
\text { Sorumluluğu }\end{array}$ & 9 & $11-36$ & $20,52 \pm 4,88$ \\
$\begin{array}{l}\text { Fiziksel Aktivite } \\
\text { Beslenme }\end{array}$ & 8 & $8-32$ & $16,67 \pm 4,71$ \\
Manevi Gelişim & 9 & $11-36$ & $19,91 \pm 4,22$ \\
\hline Kişilerarası & 9 & $11-36$ & $24,25 \pm 5,32$ \\
ilişkiler & 9 & $12-36$ & $23,72 \pm 5,23$ \\
Stres Yönetimi & 8 & $10-32$ & $19,20 \pm 4,17$ \\
Toplam & 52 & $77-208$ & $124,30 \pm 23,47$ \\
\hline
\end{tabular}

\section{Biçimi Davranışları Arasındaki İlişkinin İncelenmesi}

Okuryazarlığı ile Sağlıklı Yasam

Araştırmaya katılan öğrencilerin sağlık okuryazarlığ 1 düzeyleri ile sağlıklı yaşam biçimi davranışları puanları arasında ilişki bulunmaya çalışılmış, veriler normal dağılım gösterdiği için "Pearson Korelasyon Analiz Yöntemi” uygulanmıştır. Tablo 5'de görüldüğü üzere "Sağlık Okuryazarlığı" düzeyleri ile "Sağlıklı Yaşam Biçimi Davranışları Ölçeği" puanları arasında istatistiksel açıdan anlamlı bir ilişki tespit edilmiştir. ( $r=0,363 ; p=0,000)$. SYBD II ölçeğinin altboyutları olan sağlık sorumluluğu, fiziksel aktivite, beslenme, manevi gelişim, kişilerarası ilişkiler, stres yönetimi puanları ile sağlık okuryazarlığı düzeyleri arasında ilişki bulunmaktadır. 


\section{SONUÇ VE ÖNERILLER}

Araştırma, İstanbul ilindeki bir özel üniversitenin Sağlık Hizmetleri Meslek Yüksekokulu öğrencilerinin sağlik okuryazarlığı ve sağlıklı yaşam biçimi davranışları arasındaki ilişkinin incelenmesi amacıyla 293 öğrencinin katılımı ile gerçekleşmiştir.

Araştırmaya katılan öğrencilerin yaş ortalamas1 20,00 $\pm 0,93$ olarak tespit edildi. Bunu araştırmaya katılanların meslek yüksekokulu öğrencileri olmasına bağlayabiliriz. Örneklem grubundaki öğrencilerin \%77,1'i (n=226) kadın, \%22,9'u $(n=67)$ erkek idi. Sağlik Hizmetleri Meslek Yüksekokullarında yapılan Bulduk ve arkadaşlarının (2017) ve Akyurt (2009)'un çalışmalarındaki kadın oranları da gösteriyor ki, kadınlar sağlık hizmetleri meslek yüksekokulunu daha fazla tercih etmektedirler. ${ }^{16-17}$ Öğrencilerin \%14,7'si (n=43) Köy/kasaba, \%21,2'si (n=62) kent merkezi, \%64,2'si $\quad(n=188) \quad$ büyükşehir doğumludur. Araştırmanın İstanbul'daki bir özel üniversitede yapılması ve öğrencilerin aileleriyle beraber İstanbul'da yaşıyor olmaları bu durumu açıklayabilir.

Öğrenci annelerinin \%72'si (n=211), babalarının ise $\% 62,5^{\prime} \mathrm{i}(\mathrm{n}=183)$ ilköğretim mezunudur. Anne-babaların eğitim durumlarının düşük seviyelerde olması ve kadınların eğitim durumlarının yüksek oranda ilkokul mezuniyeti olması dikkat çekmektedir.

Öğrencilerin vücut kitle indeks oranları $\% 13$ zayıf $(n=38), \% 67,9$ normal $(n=199)$, $\% 18,8$ kilolu $(\mathrm{n}=55), \% 0,3$ obez; kadınların $\% 16,4$ 'ü $\quad(n=37) \quad$ zayıf, \%69,9'u $(n=158)$ normal, \%13,3'ü (n=30) kilolu, \%0,4'ü (n=1) obez; erkeklerin ise \%1,5'i $(n=1)$ zayıf, $\% 61.2$ 'si $(n=41)$ normal, \%37,3'ü $(n=25)$ kilolu olarak tespit edilmiştir. Öğrencilerin genel VKI ortalamaları $22,40 \pm 3,03 \mathrm{~kg} / \mathrm{m} 2$ olarak, kadın öğrencilerin ortalaması $21,86 \pm 3,12 \mathrm{~kg} / \mathrm{m}^{2}$ olarak; erkek öğrencilerin ortalamas1 ise $24,24 \pm 3,52 \mathrm{~kg} / \mathrm{m} 2$ olarak saptanmıştır. 2016 Türkiye Sağlık araştırmalarında araştırmaya katılanlar \%4 zayif, \%42,1 normal, \%34,3 kilolu ve \%19,6 obez olarak tespit edilmiş; kadınların \% 5,6's1 zayıf, \%40,4'ü normal, \%30,1'i kilolu ve $\% 23,9$ 'u obez; erkeklerin \% 2,5'i zayıf, \%43,8'i normal, \%38,6's1 kilolu ve \%15,2'si obez olarak saptanmıştır. ${ }^{18} \mathrm{Bu}$ sonuçlar ile araştırma sonuçlarımız arasında büyük farklılıklar olması dikkat çekmektedir. Bunun nedeninin ise araştırmamızın genç nüfusa yapılmış olmasından kaynaklandığı düşünülmektedir.

Arıkan'ın (2020) üniversite öğrencileri üzerinde yaptığ 1 araştırmada kadın öğrencilerin puan ortalaması 21,50 2,99 $\mathrm{kg} / \mathrm{m}^{2}$ ve $\% 10,3$ 'ü kilolu, erkek öğrencilerin ortalamas1 $24,1 \pm 3,62 \mathrm{~kg} / \mathrm{m}^{2}$ ve $\% 25,9$ 'u kilolu olarak tespit edilmiştir. Çalışmada kadın ve erkek ortalama VKI değerlerine bakıldığında bizim araştırmamızla benzerlik göstermektedir fakat çalışmamızdaki öğrencilerin kilolu kategorisindeki yüzdelik oranlarının Arıkan'ın çalışmasındaki oranlardan fazla olması dikkat çekmektedir. ${ }^{19}$

Kronik rahatsızlığ 1 olduğunu ifade eden öğrencilerin oranı \%6,3 $\quad(n=20) \quad$ olarak belirlendi. Tuygar ve Arslan'ın (2015) Sağlık Hizmetleri Meslek Yüksekokulu öğrencilerine uyguladığı bir araştırmada öğrencilerin kronik rahatsızlık oranı $\% 10.2$, Gömleksiz'in (2019) üniversite öğrencilerine uyguladığ kronik hastalık oran1 \% 10.4 'tür. ${ }^{12,20}$ Literatür ile kıyaslandığında, araştırmamızdaki oran düşük gözükmektedir.

Sigara içtiğini ifade eden öğrencilerin oran1 \%32.1 $(n=94)$ olarak belirlendi. Türkiye Sağlık Araştırması (2016) verilerine göre Türkiye'de 15 yaş ve üzeri nüfusun \%26.5'i sigara kullanmaktadır. ${ }^{21}$ Hassoy ve arkadaşlarının (2011) İzmir'de yaptığı benzer bir araştırmada öğrencilerin \%22.1'si düzenli olarak sigara kullanmakta, Doğan ve arkadaşlarının (2017) yaptıkları bir araştırmada üniversite öğrencilerinin \%14'ü sigara kullanmaktadır. ${ }^{22,23}$ Literatüre bakıldığında araştırmamızdaki oranın yüksek olduğu görülmektedir. Sağlık alanında eğitim gören ve ilerde birer sağlık çalışanı olacak 
öğrencilerin böyle yüksek bir ortalamaya sahip olmaları dikkat çekmektedir.

Öğrencilerin sağl1k okuryazarlığ

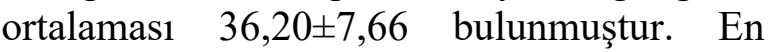
yüksek puan ortalaması "Tedavi ve Hizmet" boyutunun "bilgiyi kullanma ve uygulama" sürecinde $38,19 \pm 9,17$; en düşük puan ortalamas1 "hastal1klardan korunma ve sağlı̆̆ın geliştirilmesi" boyutunun "bilgiyi kullanma ve uygulama" sürecinde $32,77 \pm 10,53$ olarak bulunmuştur. Bu nedenle sağlık okuryazarlığının "hastalıklardan korunma ve sağlığın geliştirilmesi/ bilgiyi kullanma ve uygulama" alanı daha çok geliştirilmesi gerekmektedir. Literatür incelendiğinde Arıkan'ın (2020) üniversite öğrencilerine uyguladığı çalışmasında en düşük puan ortalaması "bilgiyi değerlendirme" süreci, Gamsızkan'ın (2020) çalışmasında ise hastalıklardan korunma ve sağlı̆̆ın geliştirilmesi/ bilgiyi değerlendirme" sürecinin en düşük puan ortalamasına sahip olduğu görülmektedir. ${ }^{19,29}$

Tanrı̈ver ve arkadaşlarının (2014) Türkiye genelinde yapmış olduğu sağlık okuryazarlığı çalışmasında sağlık okuryazarlığ 1 ortalaması 30,4 en yüksek puan 31,1 ile "Tedavi ve Hizmet" boyutunun "bilgiyi kullanma ve uygulama" sürecinde bulunmuştur. $^{28} \mathrm{Bu}$ sürecin bizim araştırmamızda da en yüksek puana sahip olması dikkat çekmektedir. Türkiye genelinde Sağlık Bakanlığ (2016) tarafindan yapılan sağlık okuryazarlığı araştırmasında ortalama puan 29,5 olarak; Arıkan'in (2020)'de üniversite öğrencilerinin sağlik okuryazarlığını ölçtüğü bir çalışmada sağlık okuryazarlığı ortalama puanı 30,76 olarak tespit edilmiştir. ${ }^{19,30}$ Çalışmamızdaki 36,20 olarak bulunan ortalamanın literatürden yüksek olmasının nedeni öğrencilerin sağlık alanında eğitim alıyor olmaları olabilir.

Araştırmamızda öğrencilerin sağlık okuryazarlığı düzeyleri \%9,60'ının $(\mathrm{n}=28)$ yetersiz, \%28,30'unun (n=83) sorunlu-sinırl, $\% 37,50$ 'sinin $(\mathrm{n}=110)$ yeterli, \%24,60'1nın $(n=72)$ mükemmel olduğu görülmektedir. Okyay ve arkadaşlarının (2016) yaptıkları Türkiye geneli sağlık okuryazarlığı araştırmasında katılımcıların sağlık okuryazarlığ düzeylerinin \%27,2'sinin yetersiz, \%42,2'sinin sorunlu, \%24,8'inin yeterli, \%5,8'inin mükemmel olduğu görülmektedir. ${ }^{13}$ Tatar (2020) tarafından yapılan benzer bir araştırmada tıp fakültesi öğrencilerinin sağl1k okuryazarlığ 1 düzeyleri $\% 10,2$ 'sinde yetersiz, \%30,0'unde sorunlusinırlı, \%33,0'ünde yeterli, \%26,8'inde mükemmel olarak tespit edilmiştir $\mathrm{Bu}$ araştırmadaki değerler ile bizim çalışmamızdaki değerlerin benzer olduğu görülmektedir. ${ }^{24}$ Bunun nedeninin ise araştırma yapılan grupların sağlık alanında eğitim alıyor olmaları olabilir.

Uluslararası çalışmalar incelendiğinde Avrupa Birliği ülkelerinde uygulanan ve sekiz ülkeyi kapsayan sağlı okuryazarlığı araştırması dikkat çekmektedir. Bu araştırma sonuçlarına göre araştırmaya katılanların $\% 12,4$ 'i yetersiz, \%35,2'si sorunlu-sinırl,, \%36's1 yeterli, \%16,5'i mükemmel düzeyde sağlık okuryazarlığına sahiptir. ${ }^{31}$ Bir diğer dikkat çeken araştırma ise Amerika'da uygulanan ulusal erişkin sağlık araştırmasına göre araştırmaya katılanların \%12'si yeterli, $\% 53$ 'ü orta düzeyde, $\% 22$ temel düzeyde, $\% 14$ temel düzeyin altında sağlık okuryazarlığına sahip olduğu tespit edilmiştir. $^{32}$

Araştırmaya katılan kadın öğrencilerin sağlık okuryazarlığı puan ortalaması $36,21 \pm 7,49 \quad(n=226) \quad$ olarak, erkek öğrencilerin $36,18 \pm 8,30(n=67)$ olarak tespit edilmiştir. Değerler birbirine çok yakındır ve aralarında anlamlı bir farklılık bulunamamıştır. Tatar'ın (2020), Dinçer ve arkadaşlarının (2017) üniversite öğrencileri ile yaptıkları çalışmalarında da bizdeki gibi kadın ve erkek öğrencilerin puanlarında anlamlı bir farklılık bulunamamıştır. ${ }^{24-25}$ Literatüre bakıldığında üniversitelerde yapılan birçok araştırmada kadın indeks puanlarının erkeklerden yüksek olduğu görülmektedir. Arıkan'ın (2020) ve Akçilek'in (2017) üniversite öğrencileri ile yaptığı araştırmalar, Ergün'ün (2017) sağlık yüksekokulu öğrencileri ile yaptığ çalışma bunlara örnek gösterilebilir. ${ }^{19,}$ 26, 27 Fakat Tanrı̈̈ver ve arkadaşlarının (2014) yapmış olduğu Türkiye genelindeki sağlık 
okuryazarlığı çalışmasında erkeklerin indeks puanları kadınlardan yüksek olduğu tespit edilmiştir. $\mathrm{Bu}$ durum ise kadınların daha düşük eğitim düzeyleri ile açıklanabilir. ${ }^{28}$

Araştırmaya katılan öğrencilerin doğum yerleri, maddi durumları, VKI siniflamaları, sınıfları ve bölümleri ile sağlık okuryazarlığı indeks puanları arasında anlamlı farklılıklar bulunmadığ1 saptanmıştır. Fakat öğrencilerin kronik hastalık durumları ile sağlık okuryazarlığı indeks puanı arasında anlamlı farklılık tespit edilmiştir $(\mathrm{p}<0,05)$. Kronik hastalığ1 olan öğrencilerin puan ortalamas1 $39,57 \pm 5,07 \quad(n=20)$ olarak; kronik hastalığ olmayan öğrencilerin puan ortalaması $35,96 \pm 7,77(\mathrm{n}=273)$ olarak tespit edilmiştir. Çalışmamızda kronik hastalığı olan öğrencilerin indeks puanlarının yüksek olması dikkat çekmektedir. Ergün'ün (2017) sağlık yüksekokulu öğrencileri ile yaptığ 1 çalışmasında bizimkisinin aksine kronik hastalığı olmayanların puan ortalamaları yüksek olduğu görülmektedir. ${ }^{27}$

Araştırmaya katılan öğrencilerin "Sağlıklı Yaşam Biçimi Davranışları II" ölçeğinden aldikları ortalama puan $124,30 \pm 23,47$ olarak tespit edilmiştir. Alınan en düşük puan 77 en yüksek puan 208 olarak saptand1. Ölçeğin "Manevi Gelişim" $(24,25 \pm 5,32)$ alt boyutunda en yüksek puan ortalamas1,

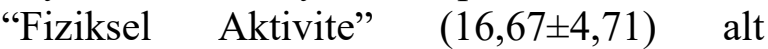
boyutunda en düşük puan ortalamas1 gözükmektedir. Literatür incelendiğinde birçok benzer sonuç ile karşılaşılmaktadır. Bozhüyük (2010) tarafından sağlık bilimleri öğrencileri ile yapılan araştırmada ortalama puan 124,30 $\pm 17,92$ olarak bulunmuş, en yüksek ortalama "Manevi Gelişim"(tinsellik), en düşük "Fiziksel Aktivite" alt boyutlarında görülmüştür. ${ }^{33}$ Tuygar ve arkadaşlarının (2015) sağlık hizmetleri yüksekokulu öğrencileri ile yaptığ 1 çalışmada ortalama puan $126.52 \pm 18.93$ bulunmuş, en yüksek ortalama "Manevi Gelişim"'(kendini gerçekleştirme), en düşük "Fiziksel Aktivite" alt boyutlarında görülmüştür. $\quad \mathrm{Bu} \quad$ sonuçlar araştırmamızdakiler ile benzerlik göstermektedir. ${ }^{12}$
Araştırmamızda cinsiyet ile SYBD II ölçeği genel puan ortalaması arasında anlamlı bir farklılık saptanmamıştır. "Fiziksel Aktivite" alt boyutunda kadınların puan ortalamasının erkeklere göre anlamlı olarak daha düşük olduğu tespit edilmiştir. Literatüre bakıldığında tıp fakültesi öğrencilerinin sağlıklı yaşam biçimi davranışlarını inceleyen Gömleksiz (2019) ve Tatar'ın (2020) çalışmalarında da fiziksel aktivite boyutunun erkeklerde yüksek olduğu görülmektedir. ${ }^{20,24} \mathrm{Bu}$ durumun nedenlerinin, ülkemizde erkeklerin spora daha fazla vakit ayırmaları, halı saha maçları vb. aktiviteleri sosyalleşme araçları olarak görmeleri ve kadınların geleneksel olarak evde daha fazla vakit geçirmeye eğilimli olmaları düşünülmektedir.

Araştırmamızda maddi durum ile SYBD II ölçeği genel puan ortalaması arasında anlamlı bir farklılık saptanmamıştır. "Beslenme" alt boyutunda maddi durumu kötü olanların anlamlı olarak puan ortalaması yüksek bulunmuştur. Araştırmamızda sigara kullanma durumu ve kronik hastalık durumu ile SYBD II puanları arasinda anlamlı farklılıklar bulunmamıştır. Bizim araştırmamızın aksine Cihangiroğlu ve arkadaşlarının (2011) sağlık yüksekokulu, Arıkan'ın (2020) üniversite öğrencileri üzerinde yaptığı çalışmalarda sigara kullanmayan öğrencilerin SYBD II puanının anlamlı olarak yüksek olduğu görülmektedir. ${ }^{34,19}$

Araştırmaya katılan öğrencilerin TSOY32 ölçeği indeks puanları ile SYBD II ve boyutları (Sağlı Sorumluluğu, Fiziksel Aktivite, Beslenme, Manevi Gelişim, Kişilerarası ilişkiler, Stres Yönetimi) arasındaki ilişkinin ortaya konabilmesi için korelasyon analizi uygulanmış ve elde edilen değerlerden istatiksel olarak anlamlı bir ilişki olduğu tespit edilmiştir. $\mathrm{Bu}$ durumda öğrencilerdeki artan sağlık okuryazarlığ düzeyinin, sağlıklı yaşam biçimi davranışlarında olumlu bir etkisinin olduğu söylenebilir. Literatür incelendiğinde yapılan benzer araştırmalarda da çalışmamızdaki gibi sağlık okuryazarlığ 1 ile sağlıklı yaşam biçimi 
davranışları arasında pozitif bir ilişki saptanmıştır. ${ }^{35,36,19,24}$

$\mathrm{Bu}$ araştırmanın sonuçları kapsamında, sağlık okuryazarlığını arttırmak için yürütülen çalışmalar çoğaltılmalı, sağlık kurumlarında ve eğitim merkezlerinde bu konu ile alakalı farkındalık oluşturulmalıdır. $\mathrm{Bu}$ sayede sağlık okuryazarlığı düşük olan hastalar ile daha güçlü iletişim sağlanabilir ve bu gruplar sağlıkla ilgili bilgiye daha kolay ulaşabilir.

Sağlık okuryazarlığı; sürekli eğitim programlarıyla desteklenmeli, liselerde ve üniversitelerde sağlık alanında eğitim almayan bölümlerin müfredatında zorunlu ders olarak bulunmalıdır. Sağlık okuryazarlığı, sağlık iletişimi, sağlık haberciliği, e-sağlik okuryazarlığı konularındaki toplum eğitimleri çoğaltılmalı, medyada bu konular ile ilgili programlar düzenlenmelidir.

Sağlık okuryazarlığını arttırmak için yeterli sağlı okuryazarlığı olmayan hastaların tespiti yapılmalı ve farklı seviyelerdeki hastalar için farklı kanallar üstünden basit, anlaşılabilir ve ulaşılabilir şekilde aktarılması gereklidir. Genç ve teknolojiye yatkın bireyler için internet üstünden, orta yaşlı bireyler için basılı medya ile, yaşı bireyler için ise televizyon kanalıyla farkındalık oluşturmak mümkün olan maksimum sayıda bireye ulaşmak açısından önem taşımaktadır. Bilgi aktarımı yaparken teknik ve tıbbi terimlerden kaçınmak, bilgiyi mümkün olduğunca günlük konuşma dilinde vermek ve görsel öğeleri yoğun şekilde kullanmak okuryazarlığın yükseltilmesi noktasında fayda sağlayacaktır.
Devlet kurumlarında, özel sektörde ve okullarda aylık veya haftalık periyotlarla sağlık okuryazarlığını arttırıcı faaliyetlerin zorunlu kılınması gereklidir.

Toplu ulaşım araçlarında bulunan ekranlar ve bilgi panoları, ulaşımda uzun saatlerini geçiren kişiler ve öğrenciler için sağlık bilgisini arttırıc1 materyaller olarak kullanılabilir. İnsanların konser, sinema, gösteri vb. amaçlarla toplandığ ikonik figürler tarafından yapılacak k1sa bilgilendirmelerle sağlık okuryazarlığı arttır1labilir.

Öğrencilerin düzenli fiziksel aktivite yapabilmeleri için okullarda ve üniversitelerde gerekli spor alanların arttırılması, takım sporlarının desteklenmesi, ücretsiz minder ve stüdyo derslerinin verilmesi sağlanmalıdır. Öğrencilerin sağlıklı beslenmeleri için yemekhanelerde diyetisyen kontrolünde hazırlanan dengeli menülerin oluşturulması, üniversite içerisindeki kantin ve kafelerde mevsimsel sebze ve meyve ağırlıklı faydalı atıştırmalık ürünlere yer verilmesi sağlanmalıdır.

Öğrencilerin sigara kullanımlarını azaltmak için, derslerde belirli periyotlarda sigaranın zararları ve neden olduğu hastalıklar hakkında bilgilendirilme yapılması, sigarayı birakmak isteyen öğrencilere destek olunması ve üniversitelerdeki sigara içme alanlarının azaltılması önerilmektedir.

Ülkemizde sağlık okuryazarlığı ve sağlıklı yaşam biçimi davranışları ile ilgili daha geniş çapta araştırmalar yapılabilir, devlet ve sağlık sektörü ile işbirlikleri yapılarak bu çalışmanın kapsamı yaygınlaştırılabilir. 


\section{KAYNAKLAR}

1. Simonds, S. K. (1974). Health Education as Social Policy. Health Educ Monogr, 1-25.

2. Balçık, P.Y, Taşkaya, S. ve Şahin, B. (2014). Sağlık Okuryazarlığı. TAF Preventive Medicine Bulletin, 13 (4), 312-326.

3. Öztürk, E.U. (2018). Sağlık Okuryazarlığı ve Önemi Biruni Sağlık ve Eğitim Bilimleri Dergisi, 1, 1-5.

4. Özbaşaran, F, Çetinkaya, A. ve Güngör, N. (2004). Celal Bayar Üniversitesi Sağlık Yüksekokulu Öğrencilerinin Sağlık Davranışları. Atatürk Üniversitesi Hemşirelik Yüksekokulu Dergisi, 7 (3), 44-45.

5. Calık, F. ve Hisar, K.M. (2019). "Bir Tıp Fakültesinde Çalışan Yardımcı Sağlık Personelinin Sağlık Okuryazarlığı". 26-30 Kasım 2019, 3.International 21.National Public Health Congress (pp.577-598), Antalya.

6. Tekin, P.Ș. (2019). Tibbi Sekreterlerde Sağlık Okuryazarlığı ve Sağlıklı Yaşam Davranışları: Öğrenci Sekreterler Boyutunda Bir Değerlendirme. Hacettepe Sağlık İdaresi Dergisi, 22 (3), 581

7. Temel, K. ve Aydın, M. (2018). Sağlık Hizmetlerinde, Hasta-Hekim İlisskisindeYaşanan Bilgi Asimetrisinin Ortaya Çıkardığı Ekonomik Sorunlar: Çanakkale Örneği. Hacettepe Sağlık İdaresi Dergisi, 21(4), 747-749.

8. Francis, L. (2008). Health Literacy for Health Center Patients and Staff. National Association of Community, $13,1-6$.

9. Yalçınkaya, M, Özer, F.G. ve Karamanoğlu, A.Y (2007). Sağlık Çalışanlarında Sağlıklı Yaşam Biçim Davranışlarının Değerlendirilmesi. TSK Koruyucu Hekimlik Bülteni, 6 (6), 410-412.

10. Özbaşaran, F, Çetinkaya, A. ve Güngör, N. (2004). Celal Bayar Üniversitesi Sağlık Yüksekokulu Öğrencilerinin Sağlık Davranışları. Atatürk Üniversites Hemşirelik Yüksekokulu Dergisi, 7 (3), 44-45.

11. Cetiner, H. ve Ulupınar, S. (2018). Sağlık Profesyoneli Olan ve Olmayan Hastane Çalışanlarının Sağlıklı Yaşam Biçimi Davranıșları. Sürekli Tıp Eğitimi Dergisi, 27 (1), $1-9$.

12. Tuygar, S.F. ve Arslan, M. (2015). Sağlık Hizmetleri Meslek Yüksekokulu Öğrencilerinin Sağlıklı Yaşam Biçimi Davranışlarının İncelenmesi. SDÜ Sağlık Bilimleri Enstitüsü Dergisi, 6 (2), 60-65.

13. Okyay, P, Abacıgil, F. ve Harlak, H. (2016). Türkiye Sağlık Okuryazarlığı Ölçeği-32. Türkiye Sağlık Okuryazarlığı Ölçekleri Geçerlik ve Güvenirlik Analizleri (s.43-55). Ankara: Sağlık Bakanlığı.

14. Bahar, Z, Beşer, A, Gördes, N, Ersin, F. ve Kıssal, A (2008). Sağlıklı Yaşam Biçimi Davranışları Ölçeği II'nin Geçerlik ve Güvenirlik Çalışması. C.Ü. Hemsirelik Yüksekokulu Dergisi, 12 (1), 2-7.

15. Ergün, A. ve Erten, S.F. (2004). Öğrencilerde Vücut Kitle İndeksi ve Bel Çevresi Değerlerinin İncelenmesi. Ankara Üniversitesi Tıp Fakültesi Mecmuası, 57 (2), 57 61 .

16. Bulduk, S, Usta, E. ve Dinçer, Y. (2017). Kültürleraras Duyarlılık ve Etkileyen Faktörlerin Belirlenmesi: Bir Sağlık Hizmetleri Meslek Yüksekokulu Örneği. Düzce Üniversitesi Sağlık Bilimleri Enstitüsü Dergisi, 7(2), 73.

17. Akyurt, N. (2009). Sağlıkta İletişim ve Marmara Üniversitesi Sağlık Hizmetleri Meslek Yüksekokulu Öğrencilerinin İletișim Becerileri . Firat Sağlik Hizmetleri Dergisi, 4, 22.
18. Turkish Statiscial Institute. (2017). Turkey Health Survey, 2016: http://www.turkstat.gov.tr/PreHaber Bultenleri.do?id=24573. (Erişim tarihi: 02/12/2020).

19. Arıkan, A. (2020). Sağlık Okuryazarlığı Düzeyinin Sağlıklı Yaşam Biçimi Davranışları Üzerindeki Etkisi: Üniversite Öğrencileri Arasında Bir Araștırma. Yüksek Lisans Tezi, Hacettepe Üniversitesi Sosyal Bilimler Enstitüsü, Ankara.

20. Gömleksiz, M. (2019). Tıp Fakültesi Öğrencilerin Sağlıklı Yaşam Biçimi Davranışları ve İlişkili Faktörler. Fırat Üniversitesi Tıp Fakültesi Dergisi, 26 (3), 151-157.

21. Turkish Statistical Institute. (2016). Turkey health survey: http://www.turkstat.gov.tr/PreHaberBultenleri. do?id=24573. Erisim Tarihi: 01/12/2020.

22. Hassoy, H, Ergin, I, Davas, A, Durusoy, R. ve Karababa, A.O. (2011). Sağlık Meslek Yüksek Okulu Öğrencilerinde Sigara, Nargile, Sarma Tütün Kullanımını Etkileyen Faktörlerin Belirlenmesi ve Öğrencilerin Sigara, Nargile, Sarma Tütüne Başlama ve Sürdürme Konusundaki Görüşleri. Solunum Dergisi, 13 (2), 93 .

23. Doğan, B, Yörük N, Öner C, Yavuz G. ve Oğuz A (2017). Üniversite Öğrenci ve Çalışanlarının Diyabet Riski ve Beslenme Alışkanlıklarının Değerlendirilmesi. Türkiye Aile Hekimliği Dergisi, 21 (2), 50-55.

24. Tatar, M. (2020). Tıp Fakültesi Öğrencilerinde Sağlık Okuryazarlığının Sağlıklı Yaşam Biçimi Davranıșlarıyla İlişkisi ve Sağlık Okuryazarlığını Etkileyen Faktörlerin İncelenmesi. Tipta Uzmanlık Tezi, Kırıkkale Üniversitesi Tıp Fakültesi Halk Sağlığı Anabilim Dalı, Kırıkkale.

25. Dinçer, A. ve Kurşun, S. (2017). Üniversite Öğrencilerinin Sağlık Okuryazarlık Düzeylerinin Belirlenmesi. STED/Sürekli Tıp Eğitimi Dergisi, 26 (1), 20-26.

26. Akçilek, E. (2017). Üniversite Öğrencilerinde Sağlık Okuryazarlığ 1 ve Yaşam Kalitesinin İncelenmesi Yüksek Lisans Tezi, İstanbul Medipol Üniversitesi Sağlık Bilimleri Enstitüsü, İstanbul.

27. Ergün, S. (2017). Sağllk Yüksekokulu Öğrencilerinde Sağlık Okuryazarlığı. Kocaeli Medical Journal, 6 (3), 4.

28. Tanrı̈ver, M, Yildırım, H, Ready, N, Çakır, B. ve Akalın, E. (2014). Türkiye Sağlık Okuryazarlığı Araştırması (s.38-40). Ankara: Sağlık-Sen Yayınları.

29. Gamsızkan, Z. ve Sungur, M.A. (2020). Düzce Üniversitesi'nde Öğrenim Gören Öğrencilerin Sağlık Okur Yazarlık Düzeyi: Kesitsel Bir Çalışma. Türkiye Aile Hekimliği Dergisi, 24(2), 117-125.

30. Sağlık Bakanlığı. (2016). Türkiye Sağlık Okuryazarlığı Ölçekleri Güvenilirlik ve Geçerlilik Çalıșması. Ankara: Sağlık Bakanlığı Yayınları.

31. Sorensen, K, Pelikan, J.M, Röthlin, F, Ganahl, K Slonska, Z, Doyle, G, Fullam, J, Kondilis, B, Agrafiotis, D, Uiters, E, Falcon, M, Mensing, M, Tchamov, K, Broucke, S. and Brand, H. (2015). Health literacy in Europe: comparative results of the European health literacy survey (HLS-EU). European Journal of Public Health, 25(6), 1053-1058.

32. Kutner, M, Greenburg, E, Jin, Y. and Paulsen, C. The Health Literacy of America's Adults: Results from the 2003 National Assessment of Adult Literacy. NCES 2006-483. National Center for Education Statistics. 2006. 
33. Bozhüyük, A. (2010). Cukurova Üniversitesi Sağlık Bilimleri Öğrencilerinin Sağlıklı Yaşam Biçimi Davranışlarının Değerlendirilmesi. Yüksek Lisans Tezi, Çukurova Üniversitesi, Adana.

34. Cihangiroğlu, Z. ve Deveci, S.E. (2011). Furat Üniversitesi Elazı ̆ Sağlık Yüksekokulu Öğrencilerinin Sağlıklı Yaşam Biçimi Davranışları ve Etkileyen Faktörler. Firat Tip Dergisi, 78-80.

35. Sezer, A. (2012). Sağlık okuryazarlığının Sağlıklı Yaşam Biçimi Davranışlarıyla İlişkisi. Yüksek Lisans Tezi, İstanbul Üniversitesi, İstanbul.

36. Ertem, A.A. (2019). Sağlık Okuryazarlı̆̆ının Sağlık Davranışlarıyla İlişkisi (Sağlık Teknikerliği Öğrencileri Üzerine Bir Arasstırma). Doktora Tezi, Gazi Üniversitesi Sağlık Bilimleri Enstitüsü, Ankara. 